\title{
Morphometric Analysis of the Foramen Magnum in Dry Human Skulls in Northeastern Brazil
}

Jalles Dantas de Lucena ${ }^{1}$ João Victor Souza Sanders ${ }^{2}$ Hudson Martins de Brito ${ }^{2}$
Gilberto Santos Cerqueira $^{3} \quad$ Ivson Bezerra da Silva ${ }^{4}$ André de Sá Braga Oliveira ${ }^{4}$

1 Department of Morphofunctional Sciences, Universidade Federal do Ceará, Fortaleza, CE, Brazil

2 Medical School, Universidade Federal do Ceará, Fortaleza, CE, Brazil

${ }^{3}$ Department of Morphology, Medical School, Universidade Federal do Ceará, Fortaleza, CE, Brazil

${ }^{4}$ Department of Morphology, Health Science Center, Universidade

Federal da Paraíba, João Pessoa, PB, Brazil

J Morphol Sci 2019;36:97-104.
Address for correspondence Ivson Bezerra da Silva, PhD, Departamento de Morfologia, Universidade Federal da Paraíba UFPB, Conj. Pres. Castelo Branco III, S/N, João Pessoa, PB 58033-455, Brasil (e-mail: ivsonbsilva@ccs.ufpb.br).

\begin{abstract}
Keywords

- anatomy and anthropology

- brazil

- foramen magnum

- occipital bone

- skull

Introduction The successful identification of the deceased is vital to the progress of any forensic investigation. This process of identification is facilitated by the determination of age, gender, and ethnicity. One of the main biological traits to be established from skeletal remains is the gender of the individual. In situations in which there are fragmented and mutilated skeletal remains, gender determination is relatively difficult, and it becomes important to establish the accuracy of individual bones. The basal region of the occipital bone is covered by a large volume of soft tissue and is therefore in a relatively well-protected anatomical position and, as such, classification of gender using the occipital bone may prove to be useful in cases of significantly disrupted remains. The present study aims to describe and analyze the morphological aspects of the foramen magnum (FM) in the population of the northeastern region of Brazil.

Material and Methods A total of 159 dry skulls ( 88 males and 71 females) were subjected to measurement by a digital caliper (DIGIMESS ${ }^{\circledR}$, Instrumentos de Precisão Ltda., São Paulo, Brazil) and was assessed for anteroposterior diameter (APD) and transverse diameter (TD), FM area, FM index (FMI), anterior, posterior and maximum lateral intercondylar distance. The measurement of all of these parameters sought to classify the FM in nine different types.

Results The pentagonal type was the most found in males (11.31\%), and the biconvex in females (18.86\%). The less frequent type in males was the pear type (2.53\%), and in females the less frequent types were the pentagonal and the heptagonal types $(2.53 \%$ each). Using the traditional anthropological classification of Martin et al, ${ }^{13}$ the most common type of FM was the brachytrematous, with $49.68 \%$ of the total skulls. The APD, TD and FM area were higher in males than in females, only in the oval FM type.

Conclusion The sexual dimorphism of the dimensions of the FM is established. However, there is a wide variability in the shape and measures in different populations, and to our knowledge this is the first study that shows the different types of the FM in the population of the northeastern region of Brazil.
\end{abstract}

received

September 24, 2018

accepted

March 28, 2019
DOI https://doi.org/

10.1055/s-0039-1688694. ISSN 2177-0298.
Copyright $\odot 2019$ by Thieme Revinter

Publicações Ltda, Rio de Janeiro, Brazil
License terms

(요 (1) $\Theta \circledast$ 


\section{Introduction}

The foramen magnum (FM) is a large opening located at the base of the skull, belonging to the occipital bone. Its borders are very variable in shape and are formed by the anatomical regions of the occipital bone. The anterior border of the FM consists of the basilar process, the lateral border is formed by the right and left occipital condyles, and the posterior border is composed by the supraoccipital portion. ${ }^{1}$

Numerous noble and hard-to-access structures enter the skull through this foramen, the main ones being the medulla bulb, the spinal cord, the meninges, the vertebral arteries, and some spinal nerve roots. ${ }^{2}$ In addition, other structures essential for the support and for the movement of the skull in relation to the spine are associated with the limits of the FM, such as the complex that forms the atlanto-occipital joint and the membranes associated with it. ${ }^{3}$

The correlation between the morphological patterns of the FM and the gender of the corpse to which the skull belongs is relevant to the forensic practice. This approach is a relatively simple and economically accessible alternative for the sexual recognition of bodies in an advanced state of degradation, in which this identification cannot be made from superficial characteristics, as is the case of carbonized victims. $^{4,5}$

The understanding of the anatomy of the FM and its variations allows for a broader view in the radiological study of pathologies associated with it, as well as a better planning and technical refinement of the neurosurgical approaches to this region, ${ }^{6}$ such as, for example, the herniations of structures of the central nervous system (CNS) through the foramen in Arnold-Chiari Syndrome, foramen stenoses in achondroplastic patients, specific meningiomas related to this structure, bulbar tumors, and cases of platybasia with invagination of the odontoid process through the FM. ${ }^{7,8}$

The present article aims to describe and analyze the morphological aspects of the FM in the population of the northeastern region of Brazil. This knowledge can serve as a basis for therapeutic behavior in several serious neurological conditions, related or not to sexual dimorphism, as well as to forensic medicine.

\section{Material and Methods}

The present study corresponds to quantitative and qualitative research. The morphometric analysis of the FM was conducted in the Department of Morphology of the Universidade Federal da Paraíba, João Pessoa, state of Paraíba, Brazil, in the Department of Morphology of the Universidade Federal do Ceará, Fortaleza, state of Ceará, Brazil, and in the Laboratory of Anatomy of the Faculdades Integradas de Patos, Patos, state of Paraíba, Brazil. All of the universities are located in the northeastern region of Brazil. The present study involved 88 male skulls and 71 female skulls, with the gender confirmation done previously from the records of the departments. All of the skulls belonged to adults $\geq 18$ years old.

Only skulls in a good state of conservation, allowing the identification of the gender, derived from the northeastern region of Brazil, were used in the present study. Skulls of children, damaged skulls, skulls with pathological conditions, incomplete skulls, and skulls without gender identification were excluded from the study.

The skulls were classified according to their gender, based on the following Vanrell criteria: ${ }^{9} 1$-massivity; 2-supraorbital margin shape; 3-size of the occipital condyles; 4-degree of inclination of the forehead; 5 -size of the mastoid process size; and 6-degree of prominence of anatomical accidents.

The FM had its form classified according to the criteria of Aragão et al: ${ }^{10} 1$ - pear; 2-oval; 3-rounded; 4-tetragonal; 5pentagonal; 6-hexagonal; 7-heptagonal; 8-biconvex; or 9irregular. Then, with a digital caliper (DIGIMESS ${ }^{\circledR}$, Instrumentos de Precisão Ltda., São Paulo, Brazil) of $0.01 \mathrm{~mm}$ accuracy, the following FM morphometric parameters were measured (-Fig. 1):

- The criterion for the measurement of the anteroposterior diameter (APD) of the FM was the distance between the basion (the midpoint of the anterior margin of the FM) and the opisthion (the midpoint of the posterior margin of the FM). The criterion for measuring the transverse diameter (TD) was the distance between the lateral margins of the FM, at the point of the greatest lateral curvature (-Fig. 1). The area of the FM was calculated using the equations by Teixeira: ${ }^{11}$ : Area $=\pi \times[(\mathrm{APD} \times \mathrm{TD}) / 4]^{2}$; and by Routal et al ${ }^{12}$ : Area $=1 / 4 \times \pi \times$ APD $\times$ TD.

- The anterior intercondylar distance (AID), which is the minimum distance between the medial margins of the occipital condyles, the posterior intercondylar distance (PID), which is the maximum distance between the medial margins of the occipital condyles, and the maximum lateral intercondylar distance (MLID), which is the maximum distance between the lateral margins of the occipital condyles, were measured.

- Using an original anthropological formula by Martin et al, ${ }^{13}$ the FM index (FMI) was calculated as follows: $\mathrm{FMI}=\mathrm{TD} /$ APD [absolute value] or $=100 \times[$ foramen magnum breadth $(\mathrm{FmB}) /$ foramen magnum length $(\mathrm{FmL})]$ [relative value; \%]).

- Based on the APD and on the DT of the FM, its shape was divided into oval or rounded. The rounded shape was defined as a TD/APD quotient between 0.9 and 1.1 (90$110 \%$ ). Skulls with a value below or above this range were included within the oval-longitudinal or oval-horizontal types, respectively.

- Based on the FMI, ${ }^{13}$ the FM was classified into 1 of 3 three groups: dolichocephalous (oval, index $<81.9$ ), mesocephalous (flat oval, index $=81.9-85.9$ ), and brachycephalous (rounded index $>86.0$ ).

Data were presented as: mean, maximum and minimum values, standard deviation (SD) and standard error of mean (SEM). The distribution of these data was evaluated by the Kolmogorov-Smirnov test. Differences between males and females were analyzed using the Student-t test. A level of significance of $p<0.05$ was used as a criterion of significance. The IBM SPSS Statistics for Windows, Version 20.0 (IBM Corp., Armonk, NY, USA) was used for the statistical analyzes. 

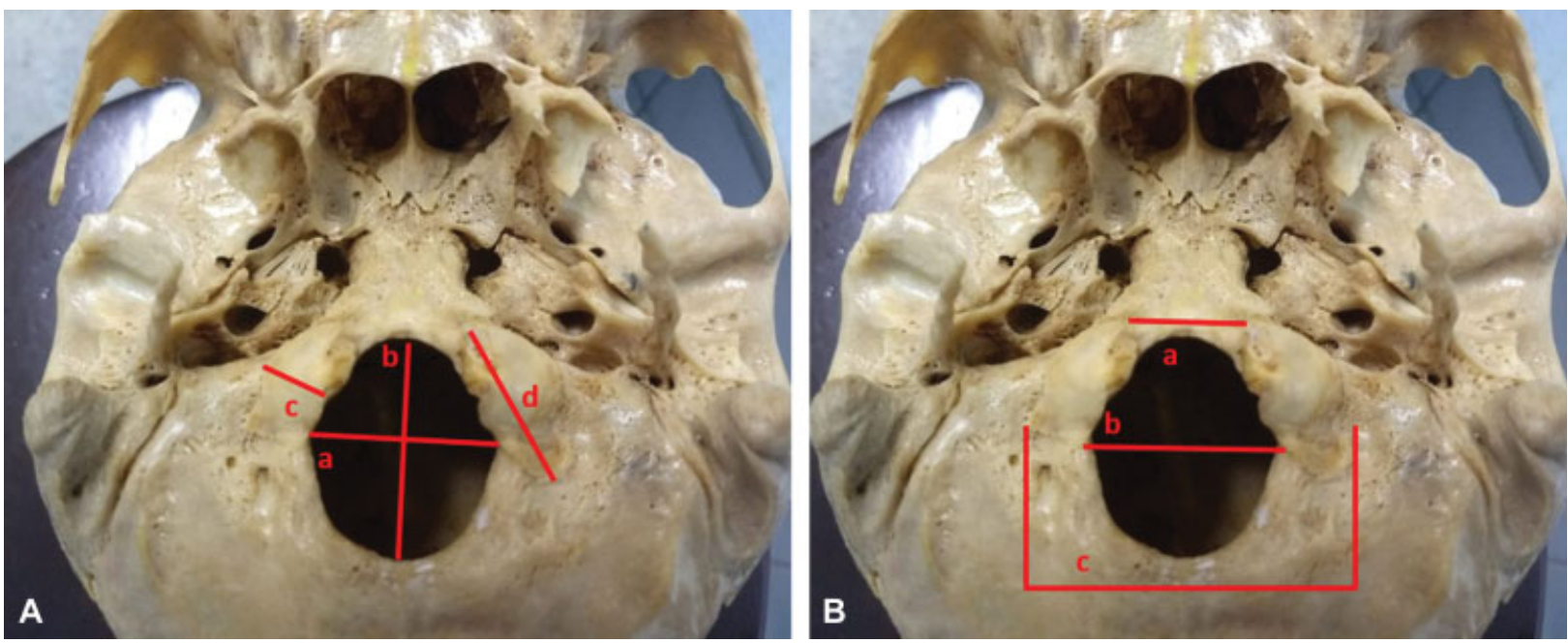

Fig. 1 An adult human skull base view. Occipital measurements. (A) a. Anteroposterior distance of the foramen magnum (APD), b. Transversal diameter of the foramen magnum (TD). (B) Adult human skull base view. Occipital measurements. a. Anterior intercondylar distance (AID), b. Posterior intercondylar distance (PID), c. Maximum lateral intercondylar distance (MLID).

\section{Results}

All of the 9 FM types that were identified by Aragão et al $^{10}$ were seen in the present study, in the evaluated population (-Table 1). In males, the FM types were separated by tetragonal, pentagonal and hexagonal, with 15, 18 and 16 cases, respectively. In females, the biconvex FM was the most common, with 19 cases. The pear type was the least frequent type in males, with 4 cases; in females, the pentagonal and heptagonal types were the least frequent, both with 4 cases (-Table 1).

The morphometric parameters of the FM recorded in dry skulls are represented in - Table $\mathbf{2}$. Differences between male and female FMs were calculated, and it was found that the dimensions were significantly higher in males compared with females ( $p<0.05$ ), except for the FMI and for the PID.

Table 1 Frequencies of the different morphological types of the foramen magnum according the classification by Aragão et al, ${ }^{10}$ in relation to gender among the examined skulls

\begin{tabular}{|l|l|l|l|l|l|l|}
\hline \multirow{2}{*}{$\begin{array}{l}\text { Shapes of the } \\
\text { foramen } \\
\text { magnum }\end{array}$} & \multicolumn{4}{|l|}{ Gender } \\
\cline { 2 - 8 } & \multicolumn{2}{|l|}{ Male } & \multicolumn{2}{l|}{ Female } & \multicolumn{2}{l|}{ Total } \\
\cline { 2 - 7 } & $n$ & $\%$ & $n$ & $\%$ & $n$ & $\%$ \\
\hline Pear & 4 & 2.53 & 9 & 5.67 & 13 & 8.2 \\
\hline Oval & 5 & 3.13 & 9 & 5.67 & 14 & 8.8 \\
\hline Rounded & 9 & 5.67 & 6 & 3.76 & 15 & 9.43 \\
\hline Tetragonal & 15 & 9.44 & 5 & 3.13 & 20 & 12.57 \\
\hline Pentagonal & 18 & 11.31 & 4 & 2.53 & 22 & 13.84 \\
\hline Hexagonal & 16 & 10.06 & 9 & 5.67 & 25 & 15.73 \\
\hline Heptagonal & 5 & 3.13 & 4 & 2.53 & 9 & 5.66 \\
\hline Biconvex & 11 & 6.95 & 19 & 11.93 & 30 & 18.86 \\
\hline Irregular & 5 & 3.13 & 6 & 3.76 & 11 & 6.91 \\
\hline Total & 88 & 55.35 & 71 & 44.65 & 159 & 100.0 \\
\hline
\end{tabular}

Using the traditional anthropological classification of Martin et $\mathrm{al}^{13}$ the most common type of FM was brachytrematous, which was observed in 79 cases in males and females. Less frequently, mesothematous (18 male and 12 female) and dolichotrematous (26 male and 24 female) types were also seen (-Table $\mathbf{3}$ ).

When the oval-type FM was analyzed, it was observed that the APD, the TD, and the FM area were higher in males than in females. However, there was no difference between these parameters in the genres studied when the FM of the rounded type was analyzed (-Table 4 ).

When the APD and the TD were compared between the oval and rounded forms of the FM, higher values of APD were observed in both genders in the oval form and higher values of TD were observed in both genders in the rounded form. There were no differences between the oval and rounded forms with respect to the FM area in both genders ( - Table 4 ).

\section{Discussion}

The differences in shape of the FM seem to be related to gender and ethnicity. ${ }^{14}$ Various studies suggest different shapes of the FM; however, the most common shapes are the oval, hexagonal, and round shapes. ${ }^{15,16}$ Based on the results of the present study, the most common forms of the FM are the tetragonal, the pentagonal and the hexagonal shapes in males, and the biconvex in females.

The FM is a morphologically variable osteological feature in the skull that has undergone evolutionary changes. ${ }^{16-18}$ The shape and morphological variations of the FM are important in neurological interpretation. In an ovoid type of the FM, for example, the surgeon may find it difficult to explore the anterior portion of the FM. ${ }^{19}$

The shape of the FM can also be determined by using the FMI. Muthukumar et al have considered the FM to be oval when the FMI was $>1.2$, and they considered the rest (FMI $<1.2$ ) as round. ${ }^{20} \mathrm{~A}$ similar sized lesion located anterior to the 
Dry Human Skulls in Northeastern Brazil de Lucena et al.

Table 2 Gender difference for the foramen magnum and other craniometric measurements in males and females

\begin{tabular}{|c|c|c|c|c|c|c|c|c|c|}
\hline \multirow[t]{2}{*}{ Variables } & \multicolumn{4}{|l|}{ Male $(n=88)$} & \multicolumn{4}{|l|}{ Female $(n=71)$} & \multirow{2}{*}{$\begin{array}{l}\text { p-value } \\
\text { (t test) }\end{array}$} \\
\hline & Range & Mean & SD & SEM & Range & Mean & SD & SEM & \\
\hline $\begin{array}{l}\text { Foramen magnum } \\
\text { anteroposterior } \\
\text { diameter }(\mathrm{mm})\end{array}$ & $29.16-43.81$ & 35.01 & 3.03 & 0.32 & $22.08-41.17$ & 33.92 & 3.19 & 0.37 & 0.028 \\
\hline $\begin{array}{l}\text { Foramen magnum } \\
\text { transverse } \\
\text { diameter }(\mathrm{mm})\end{array}$ & $22.63-37.84$ & 30.12 & 2.95 & 0.31 & $20.37-36.32$ & 28.91 & 2.83 & 0.33 & 0.010 \\
\hline $\begin{array}{l}\text { Foramen } \\
\text { magnum area } \\
\text { of Teixeira }\left(\mathrm{mm}^{2}\right)\end{array}$ & $576.93-1174.47$ & 839.83 & 131.75 & 13.44 & $429.46-1154.21$ & 773.13 & 127.94 & 14.21 & 0.001 \\
\hline $\begin{array}{l}\text { Foramen } \\
\text { magnum area } \\
\text { of Routal }\left(\mathrm{mm}^{2}\right)\end{array}$ & $570.01-1169.24$ & 833.46 & 131.34 & 13.40 & $370.73-1150.26$ & 765.47 & 130.52 & 14.50 & 0.001 \\
\hline $\begin{array}{l}\text { Foramen } \\
\text { magnum } \\
\text { index }(\mathrm{mm})\end{array}$ & $67.92-123.98$ & 86.74 & 8.61 & 0.87 & $46.00-132.60$ & 85.36 & 10.82 & 1.20 & 0.348 \\
\hline $\begin{array}{l}\text { Anterior } \\
\text { intercondylar } \\
\text { distance }(\mathrm{mm}) \\
\end{array}$ & $13.08-27.16$ & 18.81 & 2.67 & 0.33 & $9.32-28.93$ & 17.00 & 3.71 & 0.50 & 0.0028 \\
\hline $\begin{array}{l}\text { Posterior } \\
\text { intercondylar } \\
\text { distance }(\mathrm{mm})\end{array}$ & $26.97-39.38$ & 32.36 & 3.08 & 0.40 & $25.54-45.99$ & 32.86 & 5.75 & 0.78 & 0.564 \\
\hline $\begin{array}{l}\text { Maximum lateral } \\
\text { intercondylar } \\
\text { distance }(\mathrm{mm})\end{array}$ & $42.05-58.19$ & 48.73 & 3.52 & 0.45 & $38.36-57.38$ & 45.67 & 3.85 & 0.51 & 0.0001 \\
\hline
\end{tabular}

Abbreviations: SD, Standard deviation; SEM, Standard error of mean.

Table 3 Frequency of the dolichotrematous, mesotrematous and brachytrematous foramen magnume in male and female skulls

\begin{tabular}{|l|l|l|l|l|l|l|}
\hline \multirow{2}{*}{ FM type (Fm index) $^{*}$} & \multicolumn{2}{l|}{ Male $(\boldsymbol{n}=\mathbf{8 8})$} & \multicolumn{3}{l|}{ Female $(\boldsymbol{n}=71)$} \\
\cline { 2 - 7 } & $\boldsymbol{n}$ & Mean & SD & $\boldsymbol{n}$ & Mean & SD \\
\hline Dolichotrematous (<81.9) & 26 & 76.81 & 4.03 & 24 & 74.72 & 8.36 \\
\hline Mesotrematous (81.9-85.9) & 18 & 84.30 & 1.15 & 12 & 83.62 & 1.37 \\
\hline Brachytrematous (>86.0) & 44 & 92.75 & 6.07 & 35 & 92.83 \\
\hline
\end{tabular}

Abbreviation: FM, foramen magnum.

${ }^{*} \mathrm{FM}$ index (\%) according to the Martin et $\mathrm{al}^{13}$ formula $=(\mathrm{FmTD} / \mathrm{FmAPD}) \times 100 .{ }^{*}$ Standard deviation (SD).

Table 4 Diameters of the foramen magnus (mean \pm standard deviation) in male and female skulls with longitudinal oval- and round-like types of the foramen magnus

\begin{tabular}{|l|l|l|l|l|l|l|}
\hline Variables & \multicolumn{2}{|l|}{ Oval-like } & Round-like & Female & p \\
\cline { 2 - 6 } & Male & Female & -value & Male & $32.14 \pm 2.54 \#$ & $0.0001 ; 0.001$ \\
\hline $\begin{array}{l}\text { Anteroposterior } \\
\text { diameter }(\mathrm{mm})\end{array}$ & $36.02 \pm 2.97^{*}$ & $27.98 \pm 3.34$ & 0.018 & $31.00 \pm 2.07 \#$ & $30.50 \pm 2.29 \#$ & $0.011 ; 0.003$ \\
\hline $\begin{array}{l}\text { Transverse } \\
\text { diameter }(\mathrm{mm})\end{array}$ & $29.41 \pm 2.86^{*}$ & $764.34 \pm 132.38$ & 0.007 & $791.82 \pm 91.84$ & $773.56 \pm 116.54$ & \\
\hline $\begin{array}{l}\text { Foramen } \\
\text { magnum area of } \\
\left.\text { Routal (mm }{ }^{2}\right)\end{array}$ & $836.67 \pm 140.85^{*}$ & $774.63 \pm 128.13$ & 0.007 & $792.79 \pm 91.96$ & $774.42 \pm 116.61$ & \\
\hline $\begin{array}{l}\text { Foramen } \\
\text { magnum area of } \\
\text { Teixeira }\left(\mathrm{mm}^{2}\right)\end{array}$ & $846.08 \pm 141.01^{*}$ & & & & \\
\hline
\end{tabular}

*male versus female; \#oval-like versus round-like. 
Dry Human Skulls in Northeastern Brazil de Lucena et al. 101

Table 5 Comparison of the anteroposterior diameter, of the transverse diameter $(\mathrm{mm})$, and of the area $\left(\mathrm{mm}^{2}\right)$ of the foramen magnus in different populations

\begin{tabular}{|c|c|c|c|c|c|c|}
\hline Author and year & Origin & Gener & $\begin{array}{l}\text { Sample } \\
\text { size }\end{array}$ & $\begin{array}{l}\text { Anteroposterior } \\
\text { diameter }(\mathrm{mm})\end{array}$ & $\begin{array}{l}\text { Transverse } \\
\text { diameter } \\
(\mathrm{mm})\end{array}$ & $\begin{array}{l}\text { Area of the } \\
\text { foramen } \\
\text { magnus }\left(\mathrm{mm}^{2}\right)\end{array}$ \\
\hline & South America & & & & & \\
\hline \multirow[t]{2}{*}{ Present study } & \multirow[t]{2}{*}{ Brazil } & Male & 88 & $35.01 \pm 3.03$ & $30.12 \pm 2.95$ & $\begin{array}{l}839.83 \pm 131.75^{a} \\
833.46 \pm 131.34^{b}\end{array}$ \\
\hline & & Female & 71 & $33.92 \pm 3.19$ & $28.91 \pm 2.83$ & $\begin{array}{l}773.13 \pm 127.94^{\mathrm{a}} \\
765.47 \pm 130.52^{\mathrm{b}}\end{array}$ \\
\hline Pires et al, $2016^{36}$ & Brazil & $\begin{array}{l}\text { Male/ } \\
\text { Female }\end{array}$ & 77 & $34.23 \pm 2.54$ & $28.62 \pm 2.83$ & $772.4 \pm 116.7^{c}$ \\
\hline Damiani et al, $2012^{37}$ & Brazil & $\begin{array}{l}\text { Male/ } \\
\text { Female }\end{array}$ & $17 / 23$ & $34.78 \pm 2.19$ & $28.69 \pm 2.73$ & $907,25 \pm 192$ \\
\hline \multirow[t]{2}{*}{ Manoel et al, $2009^{28}$} & \multirow[t]{2}{*}{ Brazil } & Male & 139 & $35.7 \pm 0.29$ & $30.3 \pm 0.20$ & $\mathrm{n} / \mathrm{a}$ \\
\hline & & Female & 76 & $35.1 \pm 0.33$ & $29.4 \pm 0.23$ & $\mathrm{n} / \mathrm{a}$ \\
\hline \multirow[t]{2}{*}{ Suazo et al, $2009^{38}$} & \multirow[t]{2}{*}{ Brazil } & Male & 144 & $36.5 \pm 2.6$ & $30.6 \pm 2.5$ & $\mathrm{n} / \mathrm{a}$ \\
\hline & & Female & 71 & $35.6 \pm 2.5$ & $29.5 \pm 1.9$ & $\mathrm{n} / \mathrm{a}$ \\
\hline \multirow[t]{2}{*}{ Teixeira, $1982^{11}$} & \multirow[t]{2}{*}{ Brazil } & Male & 20 & $\mathrm{n} / \mathrm{a}$ & $\mathrm{n} / \mathrm{a}$ & $963.73 \pm 140^{\mathrm{a}}$ \\
\hline & & Female & 20 & $n / a$ & $\mathrm{n} / \mathrm{a}$ & $805.65 \pm 105^{a}$ \\
\hline \multirow[t]{2}{*}{ Espinoza et al, $2011^{39}$} & \multirow[t]{2}{*}{ Chile } & Male & 50 & $37.4 \pm 3.3$ & $31.9 \pm 2.6$ & $877 \pm 125$ \\
\hline & & Female & 50 & $35.6 \pm 3.0$ & $30.1 \pm 2.4$ & $798 \pm 115$ \\
\hline \multirow[t]{3}{*}{ Isaza et al, $2014^{40}$} & \multirow[t]{2}{*}{ Columbia } & Male & 121 & $22.66 \pm 2.17$ & $30.27 \pm 2.02$ & $\mathrm{n} / \mathrm{a}$ \\
\hline & & Female & 128 & $20.97 \pm 1.86$ & $27.75 \pm 2.29$ & $\mathrm{n} / \mathrm{a}$ \\
\hline & North America & & & & & \\
\hline Wanebo et al $2001^{41}$ & USA & $\begin{array}{l}\text { Male/ } \\
\text { Female }\end{array}$ & 32 & $36 \pm 3$ & $31 \pm 2$ & $608.4 \pm 121$ \\
\hline \multirow[t]{2}{*}{ Milhorat et al, $2010^{42}$} & USA & $\begin{array}{l}\text { Male/ } \\
\text { Female }\end{array}$ & $25 / 55$ & $32.5 \pm 3.17$ & $30.8 \pm 5.74$ & $787.70 \pm 118.4$ \\
\hline & Europe & & & & & \\
\hline \multirow[t]{2}{*}{ Catalina-Herrera, $1987^{43}$} & \multirow[t]{2}{*}{ Spain } & Male & 74 & $36.2 \pm 0.3$ & $31.1 \pm 0.3$ & $888.4 \pm 13.9^{\mathrm{e}}$ \\
\hline & & Female & 26 & $34.3 \pm 0.4$ & $29.6 \pm 0.3$ & $801 \pm 17.4^{\mathrm{e}}$ \\
\hline \multirow[t]{2}{*}{ Macaluso, $2011^{44}$} & \multirow[t]{2}{*}{ France } & Male & 36 & $35.38 \pm 2.27$ & $30.72 \pm 2.11$ & $\begin{array}{l}860.27 \pm 94.54^{\mathrm{a}} \\
854.80 \pm 93.79^{\mathrm{b}}\end{array}$ \\
\hline & & Female & 32 & $34.90 \pm 2.26$ & $29.40 \pm 2.63$ & $\begin{array}{l}815.13 \pm 106.29^{a} \\
807.86 \pm 107.58^{b}\end{array}$ \\
\hline \multirow[t]{2}{*}{ Gapert et al, $2009^{5}$} & \multirow[t]{2}{*}{ UK } & Male & 82 & $35.91 \pm 2.41$ & $30.51 \pm 1.77$ & $\begin{array}{l}868.95 \pm 96.36^{\mathrm{a}} \\
862.41 \pm 94.79^{\mathrm{b}}\end{array}$ \\
\hline & & Female & 76 & $34.71 \pm 1.91$ & $29.36 \pm 1.96$ & $\begin{array}{l}808.14 \pm 85.40^{\mathrm{a}} \\
801.78 \pm 85.43^{\mathrm{b}}\end{array}$ \\
\hline \multirow[t]{2}{*}{ Gapert et al, $2013^{35}$} & \multirow[t]{2}{*}{ UK } & Male & 69 & $35.79 \pm 2.36$ & $30.48 \pm 1.86$ & $\mathrm{n} / \mathrm{a}$ \\
\hline & & Female & 66 & $34.78 \pm 1.97$ & $29.35 \pm 2.06$ & $\mathrm{n} / \mathrm{a}$ \\
\hline \multirow[t]{2}{*}{ Gruber et al, $2009^{45}$} & \multirow[t]{2}{*}{ Central European } & Male & 28 & $37.1 \pm 2.7$ & $32.4 \pm 2.4$ & $\mathrm{n} / \mathrm{a}$ \\
\hline & & Female & 21 & $35.8 \pm 3.5$ & $31.0 \pm 2.8$ & $\mathrm{n} / \mathrm{a}$ \\
\hline \multirow[t]{3}{*}{ Burdan et al, $2012^{24}$} & \multirow[t]{2}{*}{ Eastern European } & Male & 142 & $37.06 \pm 3.07$ & $32.98 \pm 2.78$ & $877.40 \pm 131.64$ \\
\hline & & Female & 171 & $35.47 \pm 2.60$ & $30.95 \pm 2.71$ & $781.57 \pm 93.74$ \\
\hline & Asia & & & & & \\
\hline \multirow[t]{2}{*}{ Murshed et al, $2003^{16}$} & \multirow[t]{2}{*}{ Turkey } & Male & 57 & $37.2 \pm 3.43$ & $31.6 \pm 2.99$ & $931.7 \pm 144.29$ \\
\hline & & Female & 53 & $34.6 \pm 3.16$ & $29.3 \pm 2.19$ & $795.0 \pm 99.32$ \\
\hline
\end{tabular}

(Continued) 
Table 5 (Continued)

\begin{tabular}{|c|c|c|c|c|c|c|}
\hline Author and year & Origin & Gener & $\begin{array}{l}\text { Sample } \\
\text { size }\end{array}$ & $\begin{array}{l}\text { Anteroposterior } \\
\text { diameter }(\mathrm{mm})\end{array}$ & $\begin{array}{l}\text { Transverse } \\
\text { diameter } \\
(\mathrm{mm})\end{array}$ & $\begin{array}{l}\text { Area of the } \\
\text { foramen } \\
\text { magnus }\left(\mathrm{mm}^{2}\right)\end{array}$ \\
\hline \multirow[t]{2}{*}{ Aghakhani et al, $2016^{34}$} & \multirow[t]{2}{*}{ Iran } & Male & 50 & $37.71 \pm 1.00$ & $31.68 \pm 1.26$ & $\begin{array}{l}946.66 \pm 61.94^{\mathrm{a}} \\
939.47 \pm 62.48^{\mathrm{b}}\end{array}$ \\
\hline & & Female & 50 & $34.37 \pm 1.46$ & $28.34 \pm 1.43$ & $\begin{array}{l}773.96 \pm 70.39^{\mathrm{a}} \\
766.81 \pm 70.30^{\mathrm{b}}\end{array}$ \\
\hline \multirow[t]{2}{*}{ Routal et al, $1984^{12}$} & \multirow[t]{2}{*}{ India } & Male & 104 & $35.5 \pm 2.8$ & $32.0 \pm 2.8$ & $819.0 \pm 94^{b}$ \\
\hline & & Female & 37 & $29.6 \pm 1.9$ & $27.1 \pm 1.6$ & $771.0 \pm 90^{\mathrm{b}}$ \\
\hline \multirow[t]{2}{*}{ Jain et al, $2014^{29}$} & \multirow[t]{2}{*}{ India } & Male & 70 & $36.2 \pm 3.0$ & $31.3 \pm 2.4$ & $\begin{array}{l}909 \pm 129^{\mathrm{a}} \\
895 \pm 126^{\mathrm{b}}\end{array}$ \\
\hline & & Female & 70 & $34.0 \pm 2.7$ & $28.3 \pm 2.0$ & $\begin{array}{l}775 \pm 107^{\mathrm{a}} \\
759 \pm 102^{\mathrm{b}}\end{array}$ \\
\hline \multirow[t]{2}{*}{ Vinutha et al, $2016^{21}$} & \multirow[t]{2}{*}{ India } & Male & 100 & $33.37 \pm 2.33$ & $27.4 \pm 2.44$ & $\begin{array}{l}727.5 \pm 83.12^{\mathrm{a}} \\
718.41 \pm 83.75^{\mathrm{b}}\end{array}$ \\
\hline & & Female & 100 & $29.72 \pm 1.89$ & $24.73 \pm 2.05$ & $\begin{array}{l}583.71 \pm 63.58^{\mathrm{a}} \\
577.52 \pm 64.36^{\mathrm{b}}\end{array}$ \\
\hline \multirow[t]{3}{*}{ Madadin et al, $2017^{46}$} & \multirow[t]{2}{*}{ Saudi Arabia } & Male & 100 & $37.21 \pm 2.15$ & $31.65 \pm 2.25$ & $925.84 \pm 98.20$ \\
\hline & & Female & 100 & $36.10 \pm 2.65$ & $30.60 \pm 2.47$ & $869.80 \pm 122.75$ \\
\hline & Africa & & & & & \\
\hline \multirow[t]{2}{*}{ Ukoha et al, $2011^{47}$} & \multirow[t]{2}{*}{ Nigeria } & Male & 90 & $36.26 \pm 2.39$ & $30.09 \pm 2.58$ & $857.30^{\mathrm{d}}$ \\
\hline & & Female & 10 & $34.39 \pm 3.88$ & $28.16 \pm 1.99$ & $760.94^{d}$ \\
\hline Osunwoke et al, $2012^{48}$ & Nigeria & $\begin{array}{l}\text { Male/ } \\
\text { Female }\end{array}$ & 120 & $36.11 \pm 2.60$ & $29.56 \pm 2.60$ & $\mathrm{n} / \mathrm{a}$ \\
\hline
\end{tabular}

${ }^{\mathrm{a}}$ Area $=\pi \times[(\mathrm{APD}+\mathrm{TD}) / 4]^{2}$ (Teixeira formula). ${ }^{11}$

${ }^{\mathrm{b}}$ Area $=1 / 4 \times \pi \times$ APD $\times$ TD $\left(\right.$ Routal formula). ${ }^{12}$

${ }^{\mathrm{c}}$ Area $=1 / 4 \times \pi \times \mathrm{TD} \times$ APD (Radinsky formula). ${ }^{49}$

${ }^{\mathrm{d}}$ Area $=\pi \times r^{2}, \mathrm{C}=2 \times \pi \times r$ (Gapert formula) ${ }^{5}$

${ }^{\mathrm{e}}$ Mean \pm standard error of mean instead of standard deviation. $\mathrm{n} / \mathrm{a}$ - unknown data.

brainstem will require more extensive bone removal in a person with an ovoid FM than in a person with a round FM. In $20 \%$ of the skulls, the occipital condyle protruded significantly into the FM. As a result, a patient with a round FM, without significant protrusion of the occipital condyles into the FM, will require less bony resection than a patient with an ovoid FM with medially protuberant and sagittaly inclined occipital condyles, even though both patients present similar lesions. $^{21}$

In our study, the FMI suggested by Martin et al was considered. ${ }^{13}$ The round-like form is characterized by the index between 0.9 and 1.1 (90-110\%), while structures with a value below or above this index are called longitudinal and horizontal oval-like, respectively. Based on the index value, it is also possible to classify the FM into one of the three groups: dolichotrematous (oval; index $<81.9$ ), mesotrematous (flattened oval; index $=81.9-85.9$ ) and brachytrematous (round, index $>86.0$ ). In our study, a high predilection of brachytrematous in male and female FMs was found (79 cases). In adult native South Africans, the most common type of FM was dolichotrematous, with a low frequency of meso- and brachytrematous. ${ }^{22}$ However, a much higher value of the index (71.0-111.0\%) was present in other populations. ${ }^{5,13,23-26}$
The parameters associated with the FM, such as the APD of the FM, the TD of the FM, the AID, the MLID, and the FM area had a high sensitivity and specificity for the determination of gender; however, the FMI and the PID had less specificity.

In our study, the APD was $35.01 \mathrm{~mm}$ in males and $33.92 \mathrm{~mm}$ in females. The index shows some varieties in different studies. The APD values vary from $29.16 \mathrm{~mm}$ to $43.81 \mathrm{~mm}$ in men and from $22.08 \mathrm{~mm}$ to $41.17 \mathrm{~mm}$ in women. According to some reports, the APD is larger in men than in women. $5,15,16,24,27-33$

The TD was $28.91 \mathrm{~mm}$ in women and $30.12 \mathrm{~mm}$ in men. In other studies, the mean TD was reported differently, from $29.5 \mathrm{~mm}$ to $31.6 \mathrm{~mm}$ in men and from 27.1 to 29.4 in women; the reported diameters are larger in men than in women. 5,15,16,18,24,27-33

The FM area has been calculated between 862.41 and 931.7 $\mathrm{mm}^{2}$ in men and between 765.29 and $819.01 \mathrm{~mm}^{2}$ in women. ${ }^{4,5,16,30-33}$ In our study, various diameters were relatively smaller than those found in other studies, and it is likely that the FM in the Iranian community would be larger than in other ethnic groups. ${ }^{34}$ It seems that different ethnic groups have differences in the dimensions of the FM. Hence, it is not possible to set a specific cutoff point for all human beings. Another reason for these differences could be due to the method of measurement (via computed tomography [CT] 
scan or direct measurement of the skull). After puberty, age does not affect the size of the FM. Therefore, differences in the results of various studies could not be due to the age of the samples and there is no need to consider age while determining gender based on the dimensions of the FM. ${ }^{35}$

The degree of expression of sexual dimorphism within the FM dimensions may be explained by its development. Compared with many other skeletal elements, the FM reaches its adult size rather early in childhood and is unlikely to respond to significant secondary sexual changes. No muscles act upon the shape and size of the FM, its prime function is to accommodate the passage of structures into and out of the region of the cranial base, particularly the medulla oblongata, which occupies the greatest proportion of the space of the foramina. As the nervous system is the most precocious of all of the body systems, it reaches maturity at a very young age and, therefore, has no requirement to increase in size. This is evidenced by the completion of fusion of the different elements of the occipital bone by between 5 and 7 years of age.,21

\section{Conclusion}

Gender determination in missing or damaged skeletal remains is a major problem in forensic medicine. To this end, numerous anatomic parameters, such as shape and dimensions of the FM, should be taken into consideration to solve this problem. Since the FM has a regular structure and is located in an area that is less prone to injury, it can be used as a helpful tool for gender determination. Nevertheless, to utilize these indicators, it is required to have local data of each country and their specific regions, as there are countries, Brazil being one example, that have an extensive population. By combining qualitative data with quantitative ones, performing these studies is of great value for forensic medicine as well as for neurosurgeons.

\section{Funding}

The present research did not receive any specific grant from funding agencies in the public, commercial, or nonprofit sectors.

\section{Conflict of Interest}

The authors declare that there are no competing or financial interests associated with the present manuscript.

\section{Acknowledgments}

The authors are grateful to Mr. Benjamin D. Adam for providing help with the language.

\section{References}

1 Scheuer L, Black S. The juvenile skeleton. New York: Elsevier Academic Press; 2004

2 Moore KL, Dalley AF, Agur AMR. Anatomia Orientada para a Clínica. 7th ed. Rio de Janeiro: Guanabara Koogan; 2014

3 Bruneau M, George B. Foramen magnum meningiomas: detailed surgical approaches and technical aspects at Lariboisière Hospital and review of the literature. Neurosurg Rev 2008;31(01):19-32, discussion 32-33
4 Günay Y, Altinkök M. The value of the size of foramen magnum in sex determination. J Clin Forensic Med 2000;7(03):147-149

5 Gapert R, Black S, Last J. Sex determination from the foramen magnum: discriminant function analysis in an eighteenth and nineteenth century British sample. Int J Legal Med 2009;123(01): 25-33

6 Kanodia G, Parihar V, Yadav YR, Bhatele PR, Sharma D. Morphometric analysis of posterior fossa and foramen magnum. J Neurosci Rural Pract 2012;3(03):261-266

7 Goel A. Can foramen magnum decompression surgery become historical? J Craniovertebr Junction Spine 2015;6(02):49-50

8 Ozcetin M, Arslan MT, Karapinar B. An achondroplasic case with foramen magnum stenosis, hydrocephaly, cortical atrophy, respiratory failure and sympathetic dysfunction. Iran J Pediatr 2012;22(01):121-124

9 Vanrell JP. Odontologia legal e antropologia forense. Rio de Janeiro: Guanabara Koogan; 2002

10 Aragão JA, Pereira RO, Moraes RZC, Reis FP. Morphological Types of Foramen Magnum. Annu Res Rev Biol 2014;4:1372-1378

11 Teixeira WR. Sex identification utilizing the size of the foramen magnum. Am J Forensic Med Pathol 1982;3(03):203-206

12 Routal RR, Pal GP, Bhagawat SS, Tamankar BP. Metrical studies with sexual dimorphism in foramen magnum of human crania. J Anat Soc India 1984;2:85-89

13 Martin R, Saller K. Lehrbuch der Anthropologie. Stuttgart: Gustav Fischer Verlag; 1959

14 Burdan F, Dworzanska A, Dworzanski W, et al. Foramen Magnum New and Old Anthropological Data. G J Anthropol Res 2014; $1: 25-34$

15 Chethan P, Prakash KG, Murlimanju BV, et al. Morphological analysis and morphometry of the foramen magnum: an anatomical investigation. Turk Neurosurg 2012;22(04):416-419

16 Murshed KA, Çiçekcibaşi AE, Tuncer I. Morphometric evaluation of the foramen magnum and variations in its shape: a study on computerized tomographic images of normal adults. Turk J Med Sci 2003;33:301-306

17 Nevell L, Wood B. Cranial base evolution within the hominin clade. J Anat 2008;212(04):455-468

18 Tubbs RS, Griessenauer CJ, Loukas M, Shoja MM, Cohen-Gadol AA. Morphometric analysis of the foramen magnum: an anatomic study. Neurosurgery 2010;66(02):385-388, discussion 388

19 Sandeep A, Sharma SK, Siddiqui SW, Khatri S. Morphometry and surgical importance of foramen magnum. Int J Anat Res 2017; 5:3464-3469

20 Muthukumar N, Swaminathan R, Venkatesh G, Bhanumathy SP. A morphometric analysis of the foramen magnum region as it relates to the transcondylar approach. Acta Neurochir (Wien) 2005;147(08):889-895

21 Vinutha SP, Shubha R. Morphometry and sexual dimorphism in foramen magnum: a study of human skull bones. Int J Anat Res 2016;4:2593-2599

22 De Villiers H. The Skull of the South African Negro: A Biometrical and Morphological Study. $1^{\text {st }}$ ed. Johannesburg: Witwatersrand University Press; 1968

23 Richards GD, Jabbour RS. Foramen magnum ontogeny in Homo sapiens: a functional matrix perspective. Anat Rec (Hoboken) 2011;294(02):199-216

24 Burdan F, Szumiło J, Walocha J, et al. Morphology of the foramen magnum in young Eastern European adults. Folia Morphol (Warsz) 2012;71(04):205-216

25 Calvy TM, Segall HD, Gilles FH, et al. CT anatomy of the craniovertebral junction in infants and children. AJNR Am J Neuroradiol 1987;8(03):489-494

26 Coqueugniot H. Le crane d'Homo sapiens em Eurasie: Croissance et variation depuis 100000 ans. In: British Archaelogical Reports International Series, London: British Archaelogical Reports: 1999

27 Shanthi CH, Lokanadham S. Morphometric Study on Foramen Magnum of Human Skulls. Med Sci 2013;2:792-798 
28 Manoel C, Prado FB, Caria PHF, Groppo FC. Morphometric analysis of the foramen magnum in human skulls of brazilian individuals: its relation to gender. Braz J Morphol Sci 2009;26:104-108

29 Jain D, Jasuja OP, Nath S. Evaluation of foramen magnum in sex determination from human crania by using discriminant function analysis. El Med J 2014;2:89-92

30 Uysal S, Gokharman D, Kacar M, Tuncbilek I, Kosa U. Estimation of sex by 3D CT measurements of the foramen magnum. J Forensic Sci 2005;50(06):1310-1314

31 Sendemir E, Savci G, Cimen A. Evaluation of the foramen magnum dimensions. Kaibogaku Zasshi 1994;69(01):50-52

32 Burdan F, Umławska W, Dworzański W, et al. Anatomical variances and dimensions of the superior orbital fissure and foramen ovale in adults. Folia Morphol (Warsz) 2011;70(04):263-271

33 Raghavendra Babu YP, Kanchan T, Attiku Y, Dixit PN, Kotian MS. Sex estimation from foramen magnum dimensions in an Indian population. J Forensic Leg Med 2012;19(03):162-167

34 Aghakhani K, Kazemzadeh N, Ghafurian F, Soltani B, Soltani S. Gender determination using diagnostic values of foramen magnum. Int J Med Toxicol Forensic Med 2016;6:29-35

35 Gapert R, Black S, Last J. Test of age-related variation in the craniometry of the adult human foramen magnum region: implications for sex determination methods. Forensic Sci Med Pathol 2013;9(04):478-488

36 Pires LAS, Teixeira AR, Leite TFO, Babinski MA, Chagas CAA. Morphometric aspects of the foramen magnum and the orbit in Brazilian dry skulls. Int J Med Res Health Sci 2016;5:34-42

37 Damiani D, Borelli NS, Melo HJF, Lima RS, Nobeschi L. Morphometry and spatial correlation of the foramen magnum and spinal cord through the magnetic resonance in normal young adults anatomical and clinical aspects. J Morphol Sci 2012;29:87-90

38 Suazo GIC, Russo PP, Zavando MDA, Smith RL. Sexual dimorphism in the foramen magnum dimensions. Int J Morphol 2009;27:21-23
39 Espinoza EG, Ayala CP, Ortega LB, Collipal LE, Silva HM. Tomographic morphometry of the foramen magnum and its relation to sex and Mapuche ethnicity. Rev Anacem 2011;5:28-31

40 Isaza J, Díaz CA, Bedoya JF, Monsalve T, Botella MC. Assessment of sex from endocranial cavity using volume-rendered CT scans in a sample from Medellín, Colombia. Forensic Sci Int 2014;234:186.e1-186.e10

41 Wanebo JE, Chicoine MR. Quantitative analysis of the transcondylar approach to the foramen magnum. Neurosurgery 2001;49 (04):934-941, discussion 941-943

42 Milhorat TH, Nishikawa M, Kula RW, Dlugacz YD. Mechanisms of cerebellar tonsil herniation in patients with Chiari malformations as guide to clinical management. Acta Neurochir (Wien) 2010;152 (07):1117-1127

43 Catalina-Herrera CJ. Study of the anatomic metric values of the foramen magnum and its relation to sex. Acta Anat (Basel) 1987; 130(04):344-347

44 Macaluso PJ Jr. Metric sex determination from the basal region of the occipital bone in a documented French sample. Bull Mem Soc Anthropol Paris 2011;23:19-26

45 Gruber P, Henneberg M, Böni T, Rühli FJ. Variability of human foramen magnum size. Anat Rec (Hoboken) 2009;292(11):1713-1719

46 Madadin M, Menezes RG, Al Saif HS, et al. Morphometric evaluation of the foramen magnum for sex determination: A study from Saudi Arabia. J Forensic Leg Med 2017;46:66-71

47 Ukoha U, Egwu OA, Okafor IJ, Anyabolu AE, Ndukwe GU, Okpala I. Sexual dimorphism in the foramen magnum of Nigerian adult. Int J Biol Med Res 2011;2:878-881

48 Osunwoke EA, Oladipo GS, Gwunireama IU, Ngaokere JO. Morphometric analysis of the foramen magnum and jugular foramen in adult skulls in southern Nigerian population. Am J Sci Ind Res 2012;3:446-448

49 Radinsky L. Relative brain size: a new measure. Science 1967;155 (3764):836-838 